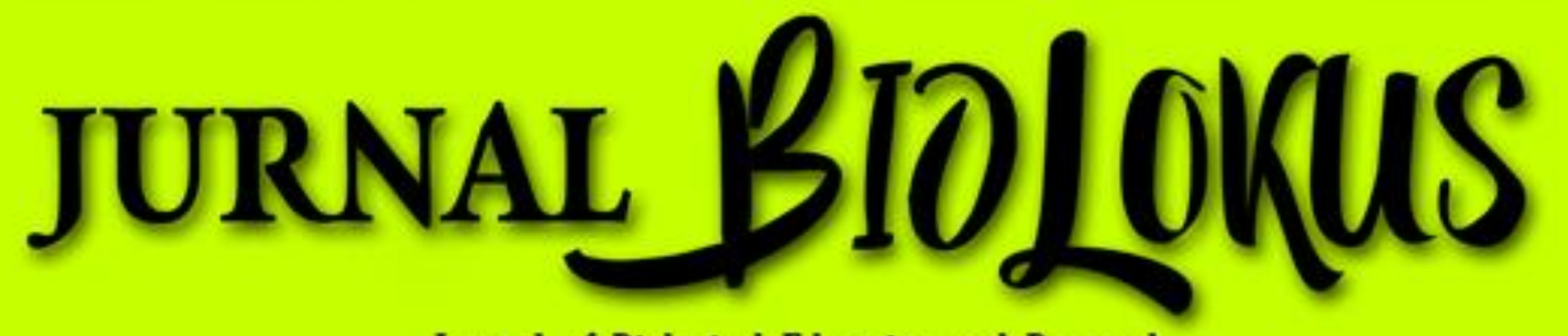

Journal of Biological Education and Research



PRODI TADRIS BIOLOGI FAKULTAS ILMU TARBIYAH DAN KEGURUAN UNIVERSTTAS ISLAM NEGERI SUMATERA UTARA 


\section{DAFTAR ISI TERBITAN}

$180-185$

186-194

195-201

202-209

210-216

$222-227$

228-233

PENGARUH MODEL PEMBELAJARAN MIND MAPPING TERHADAP HASIL BELAJAR SISWA PADA MATERI RESPIRASI DI KELAS XI SMA NEGERI 2 BILAH HULU

Rahmi Nazliah, Risma Delima Harahap, dan Elysa Rohayani Hasibuan PENGEMBANGAN MODUL BERORIENTASI PREDICT, OBSERVE, EXPLAIN (POE) PADA MATERI VIRUS TERHADAP KOGNITIF SISWA

Fitri Agustina Lubis dan Ayunda Sabrina Sormin

ANALISIS RENCANA PELAKSANAAN PEMBELAJARAN (RPP) BIOLOGI KURIKULUM 2013 KELAS X SEMESTER 1 TAHUN AJARAN 2016/2017 DI MAS ISLAMIYAH GUNTING SAGA KUALUH SELATAN KABUPATEN LABUHANBATU UTARA

Risma Delima Harahap dan Rahmi Nazliah EFEKTIVITAS PENERAPAN MODEL PEMBELAJARAN TGT (TEAMS GAMES TOURNAMENTS) TERHADAP PRESTASI BELAJAR BIOLOGI PADA SISWA KELAS XII MIA-5 MAN 3 MEDAN

Satriawati MENINGKATKAN KOMPETENSI PROFESIONAL GURU DALAM
MENYUSUN RENCANA PELAKSANAAN PEMBELAJARAN KURIKULUM
2013 MELALUI WORKSHOP DI SMP SWASTA AMANDA
Henny Ramdaniar

MENINGKATKAN HASIL BELAJAR SISWA PADA PELAJARAN ILMU PENGETAHUAN ALAM DI KELAS VII-2 MELALUI PENDEKATAN PEMBELAJARAN CARA BELAJAR SISWA AKTIF DI SMP NEGERI 29 MEDAN Sauli Farida Siregar MENINGKATKAN KEMAMPUAN KEPALA SEKOLAH DALAM MENGELOLA SEKOLAH MELALUI WORKSHOP TOTAL QUALITY MANAGEMENT DAN SUPERVISI MANAJERIAL DI SMP BINAAN

Arizona

PENINGKATAN KEMAMPUAN BERPIKIR KRITIS SISWA MELALUI MODEL PEMBELAJARAN KOOPERATIF THINK PAIR SHARE DI KELAS X SMA NEGERI 4 PADANGSIDIMPUAN

Heni Mulyani Pohan dan Ade Isma Hasibuan 


\title{
ANALISIS RENCANA PELAKSANAAN PEMBELAJARAN (RPP) BIOLOGI KURIKULUM 2013 KELAS X SEMESTER 1 TAHUN AJARAN 2016/2017 DI MAS ISLAMIYAH GUNTING SAGA KUALUH SELATAN KABUPATEN LABUHANBATU UTARA
}

\author{
Risma Delima Harahap'1 (rismadelimaharahap@gmail.com) \\ Rahmi Nazliah'1 (rahmi.nazliah@gmail.com) \\ 1Program Studi Pendidikan Biologi \\ Sekolah Tinggi Keguruan dan Ilmu Pendidikan (STKIP) Labuhanbatu
}

\begin{abstract}
ABSTRAK
Tujuan dari penelitian ini untuk menganalisis rencana pelaksanaan pembelajaran (RPP) MAS Islamiyah Gunting Saga Kualuh Selatan Kabupaten Labuhanbatu Utara berdasarkan Kurikulum 2013 yang disusun oleh guru-guru Biologi MAS Islamiyah Gunting Saga. Adapun subyek penelitian adalah guru-guru Biologi MAS Islamiyah Gunting Saga yang telah menerapkan kurikulum 2013 yang berjumlah tiga orang guru biologi. Perolehan data melalui beragam teknik pengumpulan data, diantaranya wawancara, observasi dan dokumentasi. Data dianalisis secara deskriptif. Hasil analisis data yang diperoleh dari lembar penilaian dokumen RPP guru dimana pada Instrumen rancangan penilaian sesuai dengan KI (85,0\%). Instrumen rancangan penilaian sesuai dengan KD (83,6\%). Instrumen rancangan penilaian sesuai dengan indikator $(81,7 \%)$. Instrumen rancangan penilaian telah menggunakan teknik penilaian autentik (80,0\%). Instrumen rancangan penilaian telah menggunakan bentuk penilaian sesuai pendekatan scientific dalam pembelajaran $(77,2 \%)$. Instrumen rancangan penilaian sesuai dengan materi yang diberikan (78.8\%). Instrumen rancangan penilaian sesuai waktu yang direncanakan (80,2\%). Instrumen penilaian mendukung penilaian autentik (75,2\%). Kendala yang ditemui dalam penyusunan RPP yaitu pelatihan Kurikulum 2013 baru dirasakan oleh sebagian guru biologi saja, distribusi buku terlambat sampai ke tangan guru, guru merasa bekal pemahaman tentang Kurikulum 2013 belum cukup, anggapan guru terhadap penyusunan RPP Kurikulum 2013 itu sulit, pihak sekolah hanya memberi silabus, dan berbagai alasan pribadi.
\end{abstract}

Kata Kunci : RPP, Kurikulum 2013

\section{ABSTRACT}

The purpose of this study was to analyze the plan for implementing learning (RPP) MAS Islamiyah Scissors Saga Kualuh Selatan Labuhanbatu Utara Regency based on the 2013 curriculum compile $d$ by Biology teachers MAS Islamiyah Scissors Saga. The research subjects were Biology teachers MAS Islamiyah Scissors Saga who had implemented the 2013 curriculum which amounted to three biology teachers. Obtain data through a variety of data collection techniques, including interviews, observation and documentation. Data were analyzed descriptively. The results of data analysis were obtained from the teacher RPP document assessment sheet wherein the assessment design instrument was in accordance with KI (85.0\%). The assessment design instrument is in accordance with KD (83.6\%) .The assessment design instrument is in accordance with the indicator (81.7\%). The assessment design instrument has used authentic assessment techniques (80.0\%). The assessment design instrument has used a form of assessment according to the scientific approach to learning (77.2\%). The assessment instrument is in accordance with the material provided (78.8\%). Instrument assessment design according to the planned time (80.2\%). The assessment instrument supports authentic assessment (75.2\%). Constraints encountered in the preparation of RPP namely the 2013 Curriculum training was only felt by some biology teachers, the distribution of books was too late to the hands of teachers, teachers felt that the provision of understanding about Curriculum 2013 was not enough, assuming teachers to the 2013 Curriculum RPP preparation was difficult, the school only gave syllabus, and various personal reasons.

Keywords : RPP, Curriculum 2013

\section{PENDAHULUAN}

Aktivitas yang sering dilakukan setiap individu yang bepikir yaitu pendidikan maka dari itu perlu dilakukan pengembangan potensi dan aspek kepribadian manusia. Dimana pendidikan merupakan usaha sadar dan terencana untuk 


\section{Risma D. Harahap dan R. Nazliah, Analisis Rencana Pelaksanaan Pembelajaran (Rpp) Biologi Kurikulum 2013 \\ JURNAL BIOLOKUS Vol.2 (2)}

mewujudkan suasana belajar dan proses pembelajaran agar peserta didik secara efektif mengembangkan potensi dirinya untuk memiliki kekuatan spiritual keagamaan, pengendalian diri, kecerdasan, akhlak mulia, serta keterampilan yang diperlukan oleh masyarakat, bangsa dan negara. Kurikulum 2013 adalah kurikulum yang berlaku pada saat ini pada sistem pendidikan Indonesia. Kurikulum ini merupakan kurikulum yang diterapkan oleh pemerintah untuk menggantikan kurikulum 2006 (yang sering disebut sebagai kurikulum Tingkat Satuan Pendidikan atau KTSP yang telah berlaku selama lebih kurang 6 tahun lamanya).

Materi pembelajaran yang berkaitan dengan norma atau nilai- nilai pada setiap bidang studi pendidikan perlu dikembangkan dan dihubungkan dengan konteks kehidupan sehariharinya. Sebagai acuan dalam penyelenggaraan pendidikan, ada delapan Standar Nasional Pendidikan (SNP) yang digunakan, yakni Standar Kompetensi Lulusan (SKL), Standar Isi, Standar Proses, Standar Penilaian, Standar Pendidik dan Tenaga Kependidikan, Standar Sarana dan Prasarana, Standar Pengelolaan, dan Standar Pembiayaan (Peraturan Pemerintah RI Nomor 32 Tahun 2013, Standar Nasional Pendidikan, Pasal 1). Namun seiring pemberlakuan kurikulum 2013, empat SNP yang terdiri atas SKL, Standar Isi, Standar Proses, dan Standar Penilaian mengalami perkembangan. Untuk mengembangkan kompetensi tersebut, Kurikulum 2013 mengembangkan dua model pembelajaran, yakni 1) Proses pembelajaran langsung yang menghasilkan pengetahuan dan keterampilan langsung atau yang disebut dengan instructional effect, dan 2) Proses pembelajaran tidak langsung yang menghasilkan perubahan pada diri siswa atau dikenal sebagai dampak pengiring (nurturant effect). Untuk menghasilkan dampak yang baik dalam pembelajaran tersebut, maka penting bagi seorang guru biologi untuk membuat perencanaan pembelajaran. Perencanaan merupakan langkah awal sebelum proses pembelajaran berlangsung.

Rencana Pelaksanaan Pembelajaran (RPP) merupakan rencana pembelajaran yang pengembangannya mengacu pada suatu Kompetensi Dasar (KD) tertentu yang ada di dalam kurikulum/silabus. Rencana pelaksanaan pembelajaran (RPP) dibuat dalam rangka pedoman guru dalam mengajar sehingga pelaksanaannya bisa lebih terarah, sesuai dengan Kompetensi Dasar (KD) yang telah ditetapkan. Perencanaan pembelajaran atau RPP memainkan peran penting dalam memandu guru melaksanakan tugas sebagai pendidik dalam melayani kebutuhan belajar siswasiswanya. Tanpa perencanaan yang matang, kegiatan pembelajaran tidak akan sesuai harapan. RPP merupakan salah satu komponen yang penting dan perlu diperhatikan, karena hal tersebut akan memberikan gambaran dan acuan pelaksanaan pembelajaran. RPP juga akan membantu guru dalam proses belajar mengajar berlangsung dikelas. Pembuatan RPP yang berdasarkan kurikulum 2013 haruslah dibuat dengan aturan dan rambu-rambu yang telah ditetapkan dalam kurikulum 2013. Membuat rencana pembelajaran guru harus memilih strategi pembelajaran yang benar sesuai dengan materi yang akan diajarkannya. Disamping menggunakan strategi pembelajaran yang benar, guru juga perlu mengetahui bahwa perannya tidak hanya sebagai pentransfer ilmu, namun juga sebagai motivator dan fasilitator. Dan juga mengetahui perubahan proses pembelajaran. Dimana dahulu teacher centered kini student centered, yang mana dari satu arah menuju interaktif, dari keadaan pasif menuju aktif.

Melalui penggunaan strategi yang benar, guru pun menyadari perannya serta menyadari perubahan proses pembelajaran, guru harus mampu mendesain pembelajaran yang ditentukan di Kurikulum 2013, yang mana dapat mewujudkan pembelajaran yang aktif, inovatif, kreatif, efektif, dan menyenangkan (PAIKEM) serta berpendekatan saintifik. Oleh karena itu, setiap guru mata pelajaran diwajibkan menyusun RPP, sebagaimana ditegaskan pemerintah melalui Permendikbud No. 65 Tahun 2013 tentang Standar Proses dan Permendikbud No. 81A Tahun 2013 tentang Pedoman Implementasi Kurikulum. Walaupun demikian, kenyataannya masih banyak guru yang tidak menyusun RPP. Dimana faktornya yaitu tidak memahami tentang hakikat RPP, prinsip dalam penyusunan RPP, serta menganggap bahwa menyusun RPP itu tidak perlu. Dan faktor lainnya adalah malas dalam berpikir dan bertindak untuk membuat RPP. Dampaknya banyak guru mencari jalan cepat seperti copy paste milik teman dan tinggal mengganti nama, sekolah atau tempat mengajar, yang lebih gawatnya download dari internet, yang mana situasi tersebut tidak cocok 
JURNAL BIOLOKUS Vol.2 (2)

digunakan untuk ditempat mereka mengajar, mereka memaksakan itu semua karena faktor malas membuat RPP, adapun RPP yang mereka miliki hanya sekedar memenuhi administrasi di sekolah tempat mereka mengajar. Tidak jarang RPP hanya sebagai pelengkap administrasi saja, kebanyakan dari mereka mengajar di dalam kelas tidak membawa RPP dengan alasan RPP ketinggalan di laci kantor ruang guru atau dirumah mereka dan juga mereka menganggap mengajar bisanya tanpa RPP hanya bermodalkan buku ajar saja. Dari realitas yang terjadi itulah dilakukan penelitian terhadap perangkat pembelajaran dokumen RPP yang digunakan sebagai panduan pembelajaran didalam kelas. Serta menganalisis RPP yang telah dibuat guru yang berdasarkan dengan Kurikukum 2013.

\section{METODE PENELITIAN}

Penelitian ini termasuk jenis penelitian deskriptif dimana penelitian ini berusaha untuk mendeskripsikan suatu gejala peristiwa atau kejadian secara sistematis sesuai dengan keadaan yang ada didalam suatu populasi (Dantes, 2012). Adapun subjek dalam penelitian yang dilakukan ini adalah guru-guru Biologi MAS Islamiyah Gunting Saga Kualuh Selatan Kabupaten Labuhanbatu Utara yang telah menerapkan Kurikulum 2013 disekolahnya. Adapun jumlah guru yang akan diteliti di sekolah ini berjumlah tiga orang guru biologi yang mengajar di kelas $\mathrm{X}^{1}, \mathrm{X}^{2}$ dan $\mathrm{X}^{3}$. Di sekolah ini tidak terdapat kelas unggulan. Semua kelas X di sekolah MAS Islamiyah Gunting Saga bersifat homogen. Penelitian ini dilakukan pada masa tahun ajaran 2016/2017. Sumber data yang diambil yaitu dokumen RPP yang dibuat oleh guru Biologi MAS Islamiyah Gunting Saga, angket dan wawancara. Instrumen dalam penelitian ini berupa lembar penilaian, yang digunakan untuk menilai dokumen RPP yang dimiliki guru-guru MAS Islamiyah Gunting Saga Kualuh Selatan Kabupaten Labuhanbatu Utara.

Analisis terhadap temuan penelitian di lapangan adalah untuk mengetahui perencanaan program pembelajaran (RPP) berdasarkan Kurikulum 2013 mata pelajaran biologi MAS Islamiyah Gunting Saga. Adapun rumus analisis deskriptif persentase menurut Sugiyono (2012) adalah:

$$
P=(F / N) \times 100 \%
$$

Keterangan:

$\mathrm{P}$ : Persentase

$\mathrm{F}$ : Frekuensi dari setiap jawaban yang telah menjadi pilihan responden

$\mathrm{N}$ : Jumlah responden

\section{HASIL DAN PEMBAHASAN}

Adanya Kurikulum 2013 dikembangkan berdasarkan teori yaitu "pendidikan berdasarkan standar" (standard-based education), dan teori kurikulum berbasis kompetensi (competency based curriculum). Standar pendidikan menetapkan adanya standar nasional sebagai ukuran kualitas minimal warga negara Indonesia yang mana dirinci menjadi standar isi, standar proses, standar kompetensi lulusan, standar pendidik dan tenaga kependidikan, standar sarana dan prasarana, standar pengelolaan, standar pembiayaan, dan standar penilaian pendidikan.

Kurikulum berbasis kompetensi dibuat untuk memberikan pengalaman belajar bagi peserta didik dalam mengembangkan kemampuan untuk bersikap, berpengetahuan, berketerampilan, dan bertindak. Kurikulum 2013 menganut: (1) pembelajaan yang dilakukan guru (taught curriculum) dalam bentuk proses yang dikembangkan berupa kegiatan pembelajaran di sekolah, kelas, dan masyarakat; dan (2) pengalaman belajar langsung peserta didik (learned-curriculum) sesuai dengan latar belakang, karakteristik, dan kemampuan awal peserta didik. Pengalaman belajar langsung individual peserta didik menjadi hasil belajar bagi dirinya, sedangkan hasil belajar seluruh peserta didik menjadi hasil kurikulum.

Berdasarkan Peraturan Menteri Pendidikan Nasional Republik Indonesia Nomor 16 Tahun 2007 tentang Standar Kualifikasi Akademik dan Kompetensi Guru. Dijelaskan bahwa Standar Kompetensi Guru dikembangkan secara utuh dari 4 kompetensi utama, yaitu: (1) kompetensi pedagogic; (2) kepribadian; (3) social; dan (4) profesional. Keempat kompetensi tersebut terintegrasi dalam kinerja guru. Dua diantara kompetensi tersebut berhubungan langsung dengan guru yaitu kompetensi pedagogik dan kompetensi profesional.

UU No.14 Tahun 2005 tentang guru dan dosen, seorang guru itu harus memiliki kompetensi yang diperlukan sesuai dengan bidang tugasnya, memiliki tanggung jawab atas pelaksanaan tugas keprofesionalan. Tuntutan menjadi guru yang professional, kompeten dan concern terhadap lembaga pendidikan dan peranannya sebagai agent of change, agent of transformation, memacu 


\section{Risma D. Harahap dan R. Nazliah, Analisis Rencana Pelaksanaan Pembelajaran (Rpp) Biologi Kurikulum 2013 \\ JURNAL BIOLOKUS Vol.2 (2)}

seorang guru berupaya selalu dan terus menggali potensi diri serta menambah wawasan pengetahuan (Henuhili, 2009: 161), dan salah satu indikator kompetensi pedagogik, bahwa setiap guru harus membuat rencana dalam pelaksanaan pembelajaran dan mengoptimalkan proses belajar mengajar dalam mencapai mutu hasil belajar yang berkualitas (Saragih, H 2008:27).

Hasil penelitian pada analisis dokumen RPP berdasarkan Kurikulum 2013 di MAS Islamiyah Gunting Saga Kualuh Selatan Kabupaten Labuhanbatu Utara diperoleh hasil sebagai berikut:

Tabel 1. Hasil Rekapitulasi Penilaiaan Dokumen RPP MAS Islamiyah Gunting Saga Kualuh Selatan Kabupaten Labuhanbatu Utara (Sumber Instrumen Dari Badan Pengembangan Sumber Daya Manusia Pendidikan dan Kebudayaan dan Penjaminan Mutu Pendidikan Kementerian Pendidikan Dan Kebudayaan).

\begin{tabular}{clc}
\hline No & \multicolumn{1}{c}{ Item } & Persentase \\
\hline 1 & Instrumen rancangan penilaian sesuai dengan KI. & 85,0 \\
2 & Instrumen rancangan penilaian sesuai dengan KD. & 83,6 \\
3 & Instrumen rancangan penilaian sesuai dengan indikator. & 81,7 \\
4 & Instrumen rancangan penilaian telah menggunakan teknik penilaian & \\
& & 80,0 \\
& autentik. & \\
5 & Instrumen rancangan penilaian telah menggunakan bentuk penilaian & 77,2 \\
& sesuai pendekatan scientific dalam pembelajaran. & 78.8 \\
6 & Instrumen rancangan penilaian sesuai dengan materi yang diberikan. & 80,2 \\
7 & Instrumen rancangan penilaian sesuai waktu yang direncanakan. & 75,2 \\
\hline
\end{tabular}

Hasil data lembar penilaian RPP guru MAS Islamiyah Gunting Saga Kualuh Selatan Kabupaten Labuhanbatu Utara untuk tiap - tiap komponen dapat diperjelas dengan histogram pada gambar dibawah ini :

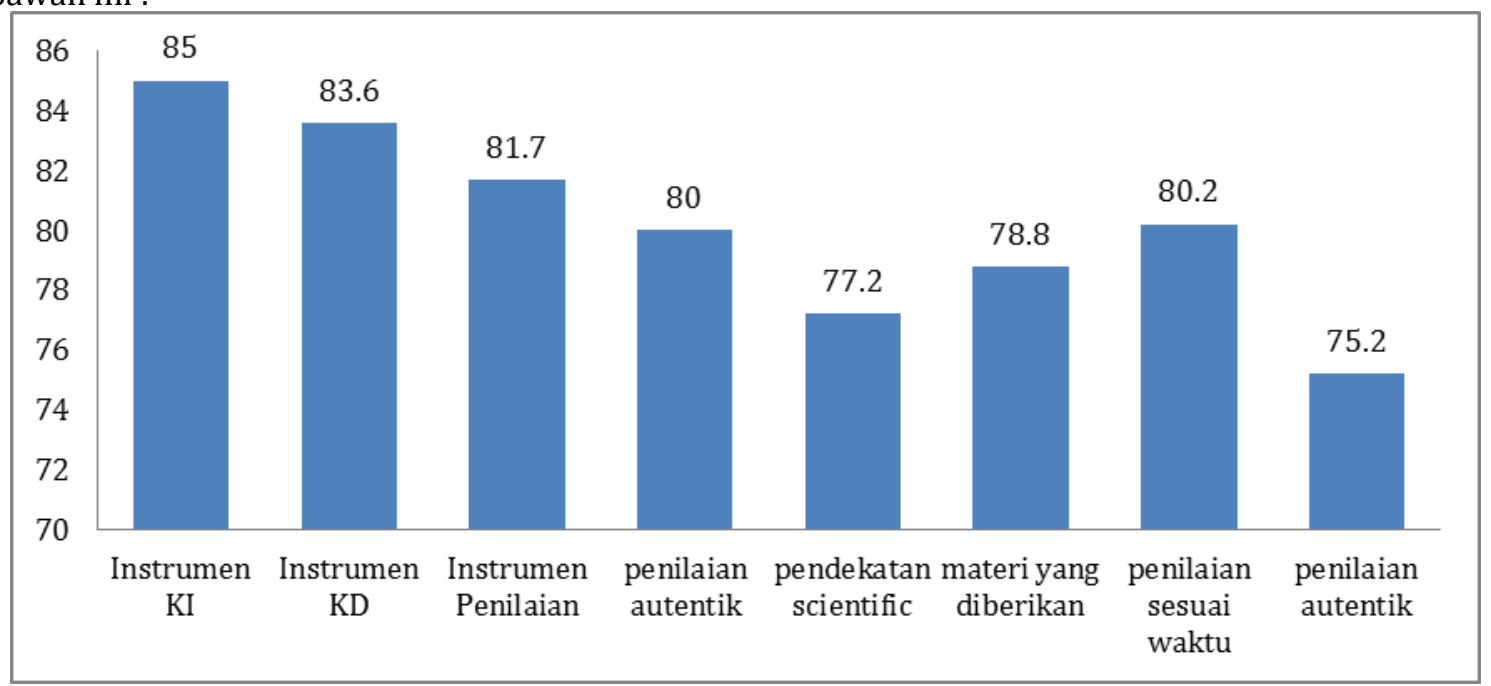

Gambar 1. Rekapitulasi Hasil Lembar Penilaian RPP guru MAS Islamiyah Gunting Saga Untuk Masing Komponen.

Histogram gambar di atas terlihat rata-rata penyusunan dokumen RPP guru-guru MAS Islamiyah Gunting Saga terlihat baik, dimana untuk instrumen rancangan penilaian sesuai dengan Kompetensi Inti dikatagorikan "baik" dengan skor mencapai $85 \%$. Pada instrumen rancangan penilaian sesuai dengan Kompetensi Dasar adalah $83,6 \%$. Instrumen rancangan penilaian sesuai dengan indikator adalah 81,7\%. Instrumen rancangan penilaian telah menggunakan teknik penilaian autentik adalah 80,0\%. Instrumen rancangan penilaian telah menggunakan bentuk penilaian sesuai pendekatan scientific dalam pembelajaran adalah $77,2 \%$. Instrumen rancangan penilaian sesuai dengan materi yang diberikan adalah 78,8\%. Instrumen rancangan penilaian sesuai waktu yang direncanakan adalah 80,2\%. Instrumen penilaian mendukung penilaian autentik adalah 75,2\%. Berdasarkan skor dari tabel diatas menyatakan bahwa dokumen RPP guru di MAS Islamiyah Gunting Saga dikatagorikan "baik". 
JURNAL BIOLOKUS Vol.2 (2)

Berdasarkan hasil wawancara dengan salah seorang guru biologi di MAS Islamiyah Gunting Saga bahwa sekolah tersebut telah menerapkan kurikulum 2013 sejak tahun 2015. Dan ini masuk tahun kedua sekolah MAS Islamiyah Gunting Saga menerapkan kurikulum 2013 yang mana sebelumnya sekolah MAS Islamiyah Gunting Saga masih menggunakan kurikulum terdahulu yaitu KTSP. Hasil wawancara terhadap guru-guru biologi di MAS Islamiyah Gunting Saga masih merasa kesulitan dalam menyusun dokumen Kurikulum 2013, hal tersebut diakibatkan masih kurangnya sarana dan prasarana yang mendukung untuk membuat rencana pelaksanaan pembelajaran terutama buku yang berbasis kurikulum 2013. Sehingga tak jarang dari guru-guru biologi MAS Islamiyah Gunting Saga mengjiplak RPP dari teman sejawat yang bekerja di lain sekolah dengan jurusan yang sama. Dan ada juga meng-copy pastekan RPP yang telah di download dari internet. Hal tersebut dikarenakan sosialisasi pembuatan RPP yang berbasis Kurikulum 2013 masih sangat minim. Pelatihan-pelatihan yang mendukung pembuatan RPP Kurikulum 2013 masih sangat jarang disosialisasikan di Kabupaten Labuhanbatu Utara. Ada pun pelatihan yang telah dilakukan tentang sosialisasi penerapan Kurikulum 2013 waktu yang digunakan menurut sebagian guru yang telah mengikuti pelatihan sangat singkat dan padat. Sehingga untuk menyusun rencana kegiatan pembelajaran belum begitu mahir membuatnya pelatihannya sudah selesai, maka dari itu tidak jarang guru-guru biologi di MAS Islamiyah Gunting Saga men-download RPP dari internet, pada hal itu tersebut sangat tidak sesuai dengan karakteristik siswa yang ada disekolah tempat mereka bertugas. Hal lain yang perlu diperhatikan yaitu ketercapaian pada pelaksanaan pembelajaran kurikulum 2013 yang telah direncanakan guru dengan membuat RPP yang baik dan benar. Dengan adanya pelaksanaan tersebut bisa dijadikan evaluasi terhadap RPP yang telah dibuat oleh guru mata pelajaran. Hal ini sesuai penelitian Simatupang, $\mathrm{H}$ (2019) pada sekolah swasta di Medan dengan mengobservasi RPP diketahui persentase ketercapaian aspek pelaksanaan pembelajaran Kurikulum 2013 di sekolah tersebut berdasarkan observasi secara menyeluruh 83,9\% dengan kategori ketercapaian Baik.

Berdasarkan hasil observasi dilapangan mengenai RPP bahwa dokumen RPP yang dibuat oleh guru-guru biologi MAS Islamiyah Gunting Saga merupakan editan dari teman-teman sepengajaran yang mengajar di sekolah lain dengan jurusan yang sama yaitu biologi, hal tersebut dapat diamati dengan melihat dokumen RPP dan mencocok kan nilai observasi dengan hasil wawancara di sekolah MAS Islamiyah Gunting Saga Kualuh Selatan.

\section{KESIMPULAN DAN SARAN Simpulan}

Berdasarkan hasil penelitian dan pembahasan diperoleh simpulan sebagai berikut: Guru-guru biologi di Madrasah Aliyah Swasta (MAS) Islamiyah Gunting Saga Kualuh Selatan Kabupaten Labuhanbatu Utara telah mampu membuat dokumen RPP dengan katagori cukup baik karena telah membuat dokumen RPP sesuai dengan aturan yang diterapkan di Kurikulum 2013.

\section{Saran}

Saran-saran yang dapat diberikan dari hasil penelitian ini adalah Pemerintah Kabupaten Labuhan batu Utara harus memperhatikan pendidikan yang ada dikabupatennya, terutama mengenai sosialisasi penerapan Kurikulum 2013. Waktu pelaksanaan pelatihan Kurikum 2013 diperbanyak sehingga guru-guru yang mengikuti pelatihan benar-benar mengerti dalam membuat dokumen perencanaan pelaksanaan pembelajaran dikelasnya. Perlu dilengkapi sarana dan prasarana yang menunjang Kurikulum 2013.

\section{REFERENSI}

Afandi, M. (2009). PERENCANAAN PEMBELAJARAN PENDIDIKAN DASAR. Khasanah Pendidikan Jurnal Ilmiah Kependidikan. 1(2), 147-161.

Arsyad, A. (2000). Media Pengajaran. Jakarta : Raja Grafindo Persada.

Astriningrum, I. (2010). Identifikasi Kesulitan Guru IPA Biologi dalam Pengembangan Silabus dan RPP mata Pelajaran IPA Biologi SMP Kecamatan Cepogo Kabupaten Boyolali. Muhammadiyah Surakarta. Skripsi (Tidak Dipublikasikan).

E. Kosasih. (2014). Strategi Belajar dan Pembelajaran Implementasi Kurikulum 2013. Bandung: Yrama Widya. 
JURNAL BIOLOKUS Vol.2 (2)

E. Mulyasa. (2013). Pengembangan dan Implementasi Kurikulum 2013. Bandung: Remaja Rosdakarya.

Hamid, A \& Hanum, I. (2009). PERENCANAAN DAN EVALUASI PEMBELAJARAN BERBASIS ANEKA SUMBER. Jurnal Teknologi Pendidikan 2 (1), 12-24.

Harsono. (2008). PENERAPAN METODE CERAMAH, DISKUSI, DAN TANYA JAWAB UNTUK MENINGKATKAN MOTIVASI BELAJAR SISWA KELAS X PADA MAN MODEL PALU. Derap Pendidikan LPMP Sulawesi Tengah 2 (3), 12-28.

Henuhili, A., \& Setianingsih. (2009). PELATIHAN PEMBUATAN MEDIA PEMBELAJARAN BIOLOGI BERBASIS INTERNET BAGI GURU BIOLOGI SMA DI KABUPATEN SLEMAN. Inotek. 13(2), 161-171.

Hutagaol, M., dan Sitompul, H. (2004). HUBUNGAN ANTARA PENGETAHUAN DASAR KEPENDIDIKAN DAN PENGUASAAN MATERI PENGAJARAN DENGAN KETERAMPILAN MENGAJAR GURU SLTP NEGERI KOTA MEDAN. Jurnal Penelitian Bidang Pendidikan, 10(2),167-176.

Majid, Abdul. (2009). Perencanaan Pembelajaran (Mengembangkan Standar Kompetensi Guru). Bandung: PT. Remaja Rosdakarya.

Peraturan Pemerintah Republik Indonesia Nomor 74 Tahun 2008 tentang Guru.

Riana, I Gede Arnawa. Agung, Gede A. Parmiti, Desak Putu. (2016). ANALISIS RENCANA PELAKSANAAN PEMBELAJARAN (RPP) UNTUK IMPLEMENTASI KURIKULUM 2013 DI SD NEGERI 3 BANJAR JAWA KECAMATAN BULELENG TAHUN PELAJARAN 2015/2016. Jurnal Teknologi Pendidikan. 5 (2).

Sadiman, A. R. (2005). Media Pendidikan, Pengertian, Pengembangan dan Pemanfaatan. Jakarta : Raja Grafindo Persada.
Samani, M. (2006). Mengenal Sertifikasi Guru di Indonesia. Surabaya : Penerbit SIC dan Asosiasi Peneliti Pendidikan Indonesia.

Salinan Lampiran Peraturan Menteri Pendidikan dan Kebudayaan RI No. 65 Tahun 2013, Standar Proses Pendidikan Dasar dan Menengah.

Salinan Lampiran Peraturan Menteri Pendidikan dan Kebudayaan No. 54 Tahun 2013, Standar Kelulusan Pendidikan Dasar dan Menengah.

Salinan Lampiran Peraturan Menteri Pendidikan dan Kebudayaan No. 64, Standar Isi Pendidikan Dasar dan Menengah.

Salinan Lampiran Peraturan Menteri Pendidikan dan Kebudayaan RI No. 59, Kurikulum 2013 $S M A / M A$.

Salinan Peraturan Menteri Pendidikan dan Kebudayaan No. 81 A Tahun 2013, Implementasi Kurikulum.

Salinan Peraturan Pemerintah RI Nomor 32 Tahun 2013, Perubahan atas Peraturan Pemerintah Nomor 19 Tahun 2005 Tentang Standar Nasional Pendidikan.

Simatupang, H., \& Purnama, D. (2019). ANALISIS PELAKSANAAN KURIKULUM 2013 DITINJAU DARI STANDAR PROSES DALAM PEMBELAJARAN IPA KELAS VII SMP AL-ULUM KOTA MEDAN. Jurnal Biolokus, 2(1), 135-138.

Sukmadinata, N. (2002). Pengembangan Kurikulum Teori dan Praktek. Bandung : Remaja Rosdakarya.

Listyo. P, Sugeng dan Faridah Nurmaliyah. (2010) Perencanaan Pembelajaran. Malang : UIN Maliki Press.

Sugiyono (2012). Prosedur Penelitian. Jakarta : Rineka Cipta.

Kementerian Pendidikan dan Kebudayaan (2014), Modul Pelatihan Implementasi Kurikulum 2013. Jakarta: BPSDMP dan PMP. 
Risma D. Harahap dan Rahmi Nazliah, Analisis Rencana Pelaksanaan Pembelajaran (Rpp) Biologi Kurikulum 2013

JURNAL BIOLOKUS Vol.2 (2)

Utami, B. dkk 2016. Analisis Rencana Pelaksanaan

Pembelajaran Tematik Yang Disusun Guru SD.

Seminar Nasional Pendidikan Sains.

Pendidikan Kimia FKIP UNS, Surakarta.

Winaya, Kadek. dkk. (2015). Analisis Rencana

Pelaksanaan Pembelajaran Menurut

Kurikulum 2013 Kelas IV SD No. 4 Banyuasri.

Jurnal Teknologi Pendidikan, 3 (1). 